\title{
FAKTOR-FAKTOR YANG MEMPENGARUHI PROFITABILITAS PERUSAHAAN MANUFAKTUR YANG TERDAFTAR DI BURSA EFEK INDONESIA PERIODE 2014-2018
}

\author{
Jen Erika Marintan Sianturi ${ }^{1)}$, Anjelina ${ }^{2)^{*}}$ \\ ${ }^{1}$ Akuntansi Manajerial, Politeknik Negeri Batam \\ email: jeinerika@gmail.com \\ 2 Akuntansi Manajerial, Politeknik Negeri Batam \\ email: anjelina@polibatam.ac.id
}

\begin{abstract}
This study aims to determine the effect of company size, working capital, efficiency, liquidity and leverage on company profitability. The population in this study are manufacturing companies listed on the Indonesia Stock Exchange for the 2014-2018 period. The number of samples used was 104 companies using purposive sampling technique. This study uses secondary data with database collection techniques. The data analysis technique used panel data regression analysis. The results of the study found that company size, efficiency, liquidity and leverage have a positive and significant effect on company profitability, while working capital has a negative and insignificant effect on company profitability. Future research is expected to use samples other than the manufacturing sector and different measurements for the profitability variable in order to see the comparison of research results.
\end{abstract}

Keywords: Profitability, Company Size, Working Capital, Efficiency, Liquidity and Leverage

\begin{abstract}
ABSTRAK
Penelitian ini bertujuan untuk mengetahui pengaruh ukuran perusahaan, modal kerja, efisiensi, likuiditas dan leverage terhadap profitabilitas perusahaan. Populasi dalam penelitian ini adalah perusahaan manufaktur yang terdaftar di Bursa Efek Indonesia untuk periode 2014-2018. Jumlah sampel yang digunakan sebanyak 104 perusahaan dengan menggunakan teknik purposive sampling. Penelitian ini menggunakan data sekunder dengan teknik pengumpulan basis data. Teknik analisis data menggunakan analisis regresi data panel. Hasil penelitian menemukan bahwa ukuran perusahaan, efisiensi, likuiditas dan leverage memiliki pengaruh positif dan signifikan terhadap profitabilitas perusahaan, sedangkan modal kerja berpengaruh negatif dan tidak signifikan terhadap profitabilitas perusahaan. Penelitian selanjutnya diharapkan dapat menggunakan sampel selain sektor manufaktur dan pengukuran yang berbeda untuk variabel profitabilitas agar dapat melihat perbandingan hasil penelitian.
\end{abstract}

Keywords: Profitabilitas, Ukuran Perusahaan, Modal Kerja, Efisiensi, Likuiditas dan Leverage 


\section{PENDAHULAN}

Meningkatnya perkembangan ekonomi saat ini sangat berpengaruh terhadap keberlangsungan perusahaan di masa yang akan datang sehingga diperlukan strategi agar dapat memaksimalkan kinerjanya (Alarussi \& Alhaderi, 2018). Terdapat beberapa hal yang mempengaruhi keberhasilan kinerja tersebut, salah satunya adalah profitabilitas perusahaan itu sendiri. Profitabilitas merupakan suatu rasio yang digunakan untuk mengukur kinerja atau kemampuan perusahaan dalam memperoleh atau menghasilkan laba. Pihak manajemen perlu mengetahui tingkat kemampuan perusahaan dalam memaksimalkan keuntungan yang diperoleh dengan mengetahui faktor-faktor apa saja yang mempunyai pengaruh besar terhadap profitabilitas. Besar kecilnya suatu perusahaan dapat diukur dari tingkat penjualan yang dihasilkan. Semakin banyak penjualan akan meningkatkan profitabilitas. Sama hal nya dengan semakin besar ukuran perusahaan akan berdampak pada kemampuan perusahaan dalam menjangkau luas nya pangsa pasar guna melakukan pemasaran terhadap produknya, sehingga berpeluang akan menghasilkan laba yang lebih besar. Hal ini sejalan dengan penelitian yang dilakukan oleh Barus \& Leliani (2013) dan Olang (2017).

Perusahaan dapat bertahan lama jika manajer keuangan bisa mengelola modal kerja dengan benar. Menurut Kasmir (2016) modal kerja merupakan suatu modal yang diperlukan perusahaan untuk membiayai kegiatan operasionalnya sehari-hari, khususnya untuk jangka waktu yang pendek. Penelitian yang dilakukan oleh Tnius (2018) mengungkapkan bahwa modal kerja memiliki pengaruh signifikan terhadap profitabilitas sehingga bisa disimpulkan semakin besar jumlah modal kerja yang dikeluarkan maka profitabilitas yang diterima perusahaan akan semakin meningkat. Ruspandi \& Asma (2014) menyebutkan bahwa dengan pengelolaan yang tepat terhadap biaya modal akan menambah efisiensi biaya operasional sehingga peluang untuk meningkatkan profitabilitas perusahaan akan semakin besar. Sejalan dengan penelitian (Alarussi \& Alhaderi, 2018) yang mengungkapkan bahwa efisiensi dari manajer bergantung pada kemampuan mereka untuk mengidentifikasi elemen-elemen yang dapat meningkatkan profitabilitas perusahaan.

Menurut Ghurtskaia \& Lemonjava (2018) likuiditas memiliki pengaruh signifikan terhadap profitabilitas karena tujuan perusahaan adalah untuk mempertahankan tingkat dana atau likuiditas secara tepat sehingga perlu menjaga keseimbangan diantara keduanya. Likuiditas merupakan kemampuan suatu perusahaan dalam memenuhi kewajiban atau hutang jangka pendek.Faktor selanjutnya yang mempengaruhi profitabilitas adalah leverage yang digunakan untuk mengukur kemampuan suatu perusahaan dalam melunasi semua kewajiban jangka pendek maupun jangka panjang bila suatu ketika perusahaan dilikuidasi atau dibubarkan. Hal ini sejalan dengan penelitian Olang (2017) menyebutkan dengan adanya leverage dapat memaksimalkan kinerja perusahaan sehingga akan meningkatkan keuntungan bagi perusahaan. Selain itu, perusahaan kecil bisa mengantisipasi terhadap risiko yang berhubungan dengan kebangkrutan atau kehilangan kepemilikan.

Penelitian ini merupakan replikasi dari penelitian yang telah dilakukan oleh Alarussi \& Alhaderi (2018) untuk menguji faktor-faktor apa saja yang mempengaruhi profitabilitas perusahaan yang ada di Malaysia. Perbedaan penelitian ini dari penelitian terdahulu terletak pada periode, tempat dan sampel penelitian. Periode penelitian yang digunakan oleh Alarussi \& Alhaderi yaitu pada tahun 2012-2014 sedangkan penelitian ini menggunakan periode 2014-2018. Penelitian Alarussi \& Alhaderi dilakukan di Malaysia sedangkan 
penelitian ini akan diuji di Indonesia. Sampel penelitian Alarussi \& Alhaderi adalah perusahaan non-keuangan yang terdaftar di Bursa Malaysia sedangkan pada penelitian ini khusus meneliti perusahaan manufaktur yang terdaftar di Bursa Efek Indonesia. Alasan peneliti memilih perusahaan manufaktur sebagai sampel penelitian ialah dikarenakan perusahaan manufaktur merupakan perusahaan berskala besar dibandingkan dengan perusahaan lain sehingga dapat dilakukan perbandingan antara perusahaan satu dengan perusahaan lain. Selain itu perusahaan manufaktur juga memiliki jumlah perusahaan terbanyak di Bursa Efek Indonesia

\section{KAJIAN TEORI, LITERATUR DAN PENGEMBANGAN HIPOTESIS}

\subsection{Resource Based Theory}

Resource Based Theory adalah teori yang menunjukkan kinerja perusahaan dalam meningkatkan kemampuan bersaing dengan mengembangkan sumber daya yang ada guna bisa bertahan dalam jangka panjang. Teori ini mengemukakan bahwa perusahaan dapat memperoleh keunggulan dalam bersaing dan memperoleh keuntungan maksimal dengan mengelola aset-aset yang berwujud maupun tidak berwujud.

Resource Based Theory untuk pertama kali dikemukakan oleh Wernerfelt (1984) dalam artikelnya yang berjudull“ $A$ Resource-based view of the firm". Namun teori yang paling berpengaruh dalam hal ini disampaikan lewat artikel Barney (1991) dengan judul "Firm Resource and Sustained Competitive Adventage", adapun isi dari artikel tersebut membahas mengenai keunggulan bersaing dapat dilakukan dengan memahami bahwa perusahaan mencakup elemen yang heterogen dan tidak bergerak. Menurut Barney (1991), beberapa kriteria yang harus dipenuhi perusahaan dalam memaksimalkan keunggulan bersaing diantaranya yaitu: valuable (bernilai), rare (langka), inimitable (sulit ditiru) dan nonsubstitutable (tidak dapat digantikan). Dengan memenuhi kriteria tersebut, maka sumber daya ikut berkontribusi pada keunggulan bersaing perusahaan sehingga perusahaan dapat meningkatkan profitabilitas dan mampu bersaing dengan perusahaan lain dalam satu industri, khususnya manufaktur.

\subsection{Trade Off Theory}

Trade Off Theory dipopulerkan pertama kali oleh Modigliani dan Miller pada tahun 1963 dalam artikel yang berjudul Corporate Income Taxes on the Cost of Capital: A Correction. Teori tersebut menjelaskan seberapa banyak hutang perusahaan dan ekuitas perusahaan sehingga terjadi keseimbangan antara biaya yang dikeluarkan terhadap keuntungan yang diperoleh. Berdasarkan teori ini suatu perusahaan dianggap dapat menentukan sasaran utang terhadap ekuitas dan bisa bergerak ke arah yang menunjukkan bahwa beberapa bentuk struktur modal optimal dapat meningkatkan nilai perusahaan dan profitabilitas (Sheikh dan Wang, 2011).

\subsection{Kajian Literatur}

Alarussi \& Alhaderi (2018) menguji faktor-faktor yang mempengaruhi profitabilitas di Malaysia untuk periode 2012-2014. Variabel independen dalam penelitian ini yaitu ukuran perusahaan, modal kerja, likuiditas, efisiensi, dan leverage sedangkan profitabilitas merupakan variabel dependen. Hasil dari penelitian menunjukkan ukuran perusahaan, efisiensi dan modal kerja memiliki pengaruh positif terhadap profitabilitas dan tidak memiliki pengaruh signifikan terhadap leverage dan likuiditas.

Niresh \& Velnampy (2014) menelliti hubungan antara ukuran perusahaan dan profitabilitas. Penelitian menggunakan sampel sebanyak 15 perusahaan 
Manufaktur di Sri Lanka yang terdaftar di Colombo Stock Exchange pada tahun 2008-2012. Hasil penelitian adalah ukuran perusahaan yang diproksikan dengan Total Sales dan Total Aset tidak memiliki pengaruh signifikan terhadap profitabilitas yang diproksikan dengan Net Profit dan ROA.

Paliwal \& Chouhan (2017) menguji hubungan empiris antara likuiditas dan profitabilitas perusahaan otomotif pada tahun 2010-2015. Penelitian ini dilakukan di India dan menggunakan sampel sebanyak 10 perusahaan. Hasil penelitian menunjukkan bahwa likuiditas memiliki pengaruh signifikan dan positif terhadap profitabilitas.

Olang (2017) menguji pengaruh leverage keuangan terhadap profitabilitas perusahaan yang terdaftar di Nairobi Securities Exchange. Penelitian ini mengambil sampel sebanyak 30 perusahaan yang terdaftar menggunakan teknik purposive sampling. Variabel independen adalah pertumbuhan perusahaan, ukuran perusahaan, leverage dan likuiditas sedangkan profitabilitas merupakan variabel dependen. Hasil penelitian menunjukkan bahwa leverage dan ukuran perusahaan berpengaruh signifikan terhadap profitabilitas, sedangkan pertumbuhan perusahaan dan likuiditas tidak terdapat pengaruh yang signifikan.

Barus \& Leliani (2013) menganalisis pengaruh Total Asset Turnover (TATO), current ratio (CR), Debt Ratio (DR), Debt To Equity Ratio (DER), Ukuran Perusahaan dan Pertumbuhan Penjualan terhad paprofitabilitas secara parsial dan simultan. Hasil penelitian secara parsial diketahui bahwa Ukuran Perusahaan DR dan TATO berpengaruh signifikan terhadap profitabilitas, namun tidak untuk Pertumbuhan Penjualan, CR dan DER. Penelitian secara simultan terdapat pengaruh signifikan antara semua variabel terhadap profitabilitas.
Santoso, Maryono, \& Bagana (2019) menguji faktor-faktor yang mempengaruhi profitabilitas pada perusahaan manufaktur yang terdaftar di BEI periode 2015-2017. Variabel independen dalam penelitian ini adalah Debt to Equity Ratio (DER), Current Ratio (CR), Total Asset Turnover (TATO), dan Ukuran Perusahaan (UP) sedangkan Profitabilitas (ROE) merupakan variabel dependen. Hasil dari penelitian adalah Current Ratio, Total Asset Turnover, dan Ukuran Perusahaan memiliki pengaruh signifikan terhadap profitabilitas namun tidak pada Debt to Equity Ratio.

\subsection{Pengembangan Hipotesis}

\subsubsection{Pengaruh Ukuran Perusahaan terhadap Profitabilitas \\ Ukuran perusahaan adalah} kemampuan perusahaan dalam memenuhi berbagai keperluan produksi dan menentukan jumlah aktiva yang diperoleh perusahaan (Rahmawati, Topowijono, \& Sulasmiyati, 2015). Menurut Santoso, Maryono, \& Bagana (2019), ukuran perusahaan dapat ditentukan dari perolehan aset yang dimiliki oleh perusahaan. Semakin besar jumlah aset yang dimiliki maka semakin besar pula tingkat perolehan laba sehingga dapat meningkatkan profitabilitas perusahaan. Hal ini sejalan dengan ukuran dari sebuah perusahaan. Semakin besar ukuran perusahaan akan memberikan kesempatan bagi perusahaan dalam menjangkau pangsa pasar yang lebih luas untuk melakukan penjualan terhadap produknya, sehingga peluang untuk memperoleh laba juga akan semakin meningkat. Ukuran perusahaan memiliki pengaruh positif terhadap profitabilitas didukung oleh Nugroho (2011), Barus \& Leliani (2013), Santoso, Maryono, \& Bagana (2019), Alarussi \& Alhaderi (2018) dan Olang (2017). Berdasarkan uraian diatas, maka hipotesis pertama yang akan diuji oleh peneliti adalah: 
H1: Ukuran perusahaan berpengaruh positif terhadap Profitabilitas

\subsubsection{Pengaruh Modal Kerja terhadap Profitabilitas}

Salah satu komponen utama yang harus dimiliki perusahaan dalam menjalankan aktivitas perusahaan adalah modal kerja. Tersedia nya modal kerja yang cukup akan memungkinkan perusahaan untuk beroperasi dan apabila penggunaan modal kerja dilakukan secara produktif, perolehan laba yang dihasilkan perusahaan akan meningkat (Putri, Safitri, \& Wijaya, 2014). Sebaliknya, penggunaan yang tidak produktif dengan menggunakan modal kerja secara berlebihan akan memberikan kerugian karena dana yang digunakan tidak sepenuhnya untuk keperluan perusahaan. Tnius (2019) menyebutkan bahwa modal kerja memiliki pengaruh signifikan terhadap profitabilitas. Dengan begitu, semakin besar jumlah modal kerja yang terpakai maka perolehan profitabilitas perusahaan juga akan meningkat. Hal ini didukung penelitian oleh Alarussi \& Alhaderi (2018), Yani \& Martha (2019) dan Lindung (2015). Berdasarkan uraian diatas, hipotesis kedua yang akan diuji oleh peneliti adalah:

$\mathrm{H} 2$ : Modal Kerja berpengaruh positif terhadap Profitabilitas

\subsubsection{Pengaruh Efisiensi Perusahaan terhadap Profitabilitas \\ Menurut Sulistyono (2014) efisiensi} merupakan suatu ukuran untuk membandingkan hasil output dari suatu proses dengan hasil inputnya. Output tersebut merupakan hasil operasi dalam satu periode dari total pendapatan sedangkan input adalah total pengeluaran untuk memperoleh pendapatan tersebut. Perusahaan dengan tingkat efisiensi yang tinggi memiliki kemampuan untuk menyelesaikan semua kegiatan operasional secara tepat waktu sehingga dapat mengurangi biaya operasional dan memperoleh keuntungan maksimal, dengan begitu profitabilitas perusahaan juga akan semakin meningkat. Hal ini sejalan dengan penelitian yang dilakukan oleh Sejati (2014), Vadri, Taqwa, \& Utami (2014) dan Alarussi \& Alhaderi (2018) yang menyebutkan bahwa efisiensi perusahaan memiliki pengaruh positif terhadap profitabilitas. Berdasarkan uraian diatas, hipotesis ketiga yang akan diuji oleh peneliti adalah:

H3: Efisiensi Perusahaan berpengaruh positif terhadap Profitabilitas

\subsubsection{Pengaruh Likuiditas Perusahaan terhadap Profitabilitas \\ Menurut Gitman \& Zutter (2012)} likuiditas suatu perusahaan diukur berdasarkan kemampuan perusahaan dalam memenuhi kewajiban jangka pendek saat jatuh tempo. Dalam pengukurannya, current ratio sebagai proksi likuiditas digunakan untuk menentukan kemampuan perusahaan dalam memenuhi kebutuhan kas dalam membayar kewajiban jangka pendek maupun modal kerja untuk biaya kegiatan operasional perusahaan. Semakin meningkat current ratio suatu perusahaan, maka perusahaan akan memperoleh kepercayaan dari para kreditur dalam melakukan peminjaman dana guna menambah modal yang nantinya dapat memberikan keuntungan bagi perusahaan. Hal ini sejalan dengan penelitian yang dilakukan oleh Paliwal \& Chouhan (2017), Santini \& Baskara (2018) dan Ghurtskaia \& Lemonjava (2018) yang menyatakan bahwa likuiditas memiliki pengaruh positif dan signifikan terhadap profitabilitas. Berdasarkan uraian diatas, hipotesis keempat yang akan diuji oleh peneliti adalah:

H4: Likuiditas perusahaan berpengaruh positif terhadap profitabilitas 


\subsubsection{Pengaruh Leverage Perusahaan terhadap Profitabilitas}

Menurut Wicaksono (2016) leverage adalah penggunaan aset dan sumber dana yang mempunyai biaya tetap dengan tujuan agar meningkatkan laba bagi pemegang saham. Pendanaan yang digunakan perusahaan tidak selalu diperoleh dari modal sendiri, namun bisa juga dalam bentuk hutang yang diperoleh dari pinjaman kreditur. Leverage merupakan rasio hutang yang digunakan dalam mengukur kemampuan suatu perusahaan untuk menutupi kewajiban dalam bentuk hutang terhadap modal yang dimiliki perusahaan (Febria \& Halmawati, 2014). Menurut Singapurwoko (2011) leverage merupakan salah satu faktor yang memengaruhi profitabilitas karena dapat meningkatkan modal perusahaan guna meningkatkan keuntungan. Hal ini didukung dengan penelitian Kartikasari \& Merianti (2016), Barus \& Leliani (2013) dan Olang (2017) yang menyatakan bahwa leverage memiliki pengaruh signifikan terhadap profitabilitas. Berdasarkan uraian diatas, hipotesis kelima yang akan diuji oleh peneliti adalah:

H5: Leverage perusahaan berpengaruh positif terhadap profitabilitas

Berdasarkan uraian kajian teori, kajian literatur, dan pengembangan hipotesis yang telah dijelaskan sebelumnya, maka model penelitian dapat terlihat pada Gambar 1:

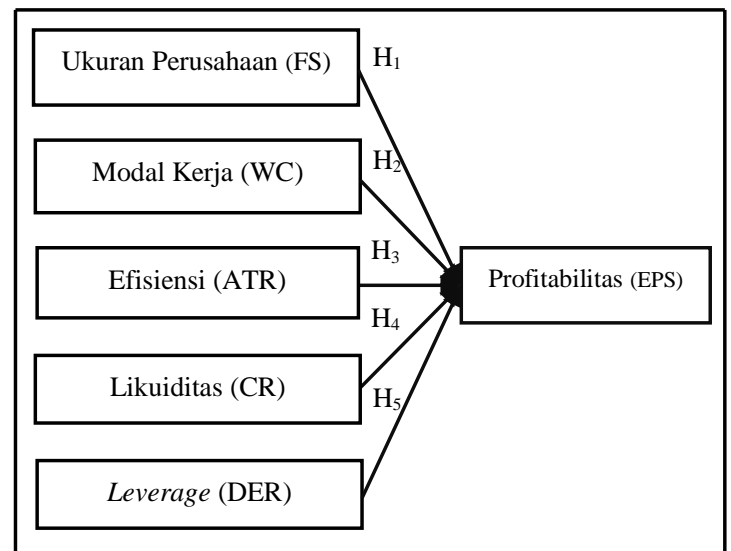

Gambar 1. Model Penelitian

Sumber: Data Diolah Sendiri, 2020

\section{METODE PENELITIAN}

\subsection{Jenis dan Sumber Data}

Penelitian ini menggunakan data sekunder berupa laporan keuangan yang terdaftar di Bursa Efek Indonesia (BEI) periode 2014-2018. Sumber data penelitian ini diperoleh dari situs www.idx.co.id. Jenis data yang digunakan pada penelitian ini adalah data rasio. Penelitian ini merupakan penelitian kuantitatif karena data yang digunakan berupa angka-angka yang akan diolah agar mudah dipahami.

\subsection{Populasi dan Sampel}

Populasi dalam penelitian ini adalah laporan keuangan perusahaan manufaktur yang terdaftar di Bursa Efek Indonesia (BEI). Teknik penarikan sampel dalam penelitian ini adalah teknik purposive sampling yang digunakan untuk menentukan sampel berdasarkan pertimbangan atau kriteria yang telah ditetapkan sebelumnya (Yusuf, 2017). Kriteria sampel dalam penelitian ini adalah erusahaan manufaktur yang terdaftar di Bursa Efek Indonesia (BEI) selama periode 2014-2018, laporan keuangan dengan periode mulai dari 1 januari sampai dengan 31 Desember yang menggunakan satuan mata uang rupiah dan data laporan keuangan harus tersedia dengan lengkap mulai dari tahun 20142018 .

\subsection{Operasional Variabel dan Pengukuran}

\subsubsection{Variabel Dependen}

Variabel dependen dalam penelitian ini adalah profitabilitas yang diproksikan menggunakan Earnings Per Share (EPS). EPS adalah rasio profitabilitas yang mengukur tingkat kemampuan per lembar saham dalam memperoleh laba. Oleh karena itu, penting bagi pemegang saham dalam EPS sebagai indikator keberhasilan suatu perusahaan. Dihitung dengan rumus sebagai berikut: 
EPS $=\frac{\text { Laba Bersih Setelah Pajak }}{\text { Jumlah Saham }}$

Sumber: Harahap (2015)

\subsubsection{Variabel Independen}

Variabel independen dalam penelitian ini terdiri dari lima variabel yaitu: ukuran perusahaan, modal kerja, efisiensi perusahaan, likuiditas perusahaan dan leverage perusahaan.

\section{a. Ukuran Perusahaan}

Ukuran perusahaan digunakan untuk melihat besar atau kecil nya suatu perusahaan dan menentukan tingkat kemudahan dalam perolehan dana dari pasar modal. Selain itu, jumlah penjualan yang dihasilkan mempengaruhi besar atau kecil nya perusahaan. Semakin banyak penjualan, maka keuntungan yang diperoleh akan bertambah sehingga bisa meningkatkan ukuran perusahaan. Dihitung dengan rumus sebagai berikut:

Ukuran Perusahaan $=$ Ln Total Aktiva

Sumber: Harahap (2015)

\section{b. Modal Kerja}

Modal kerja digunakan untuk membiayai kebutuhan operasional perusahaan sehari-hari sehingga modal kerja sangat diperlukan untuk keberlangsungan suatu perusahaan. Dihitung dengan rumus sebagai berikut:

Modal Kerja = Total Aktiva Lancar - Total Hutang Lancar

Sumber: Harahap (2015)

\section{c. Efisiensi Perusahaan}

Efisiensi perusahaan digunakan untuk mengukur keberhasilan yang dinilai dari segi besarnya biaya untuk mencapai hasil dari kegiatan yang dijalankan. Dalam penelitian ini efisiensi perusahaan diproksikan menggunakan asset turnover ratio. Rasio ini dipakai untuk mengetahui kemampuan dana dalam keseluruhan aktiva yang berputar dalam suatu periode tertentu untuk mendapatkan keuntungan. Dihitung dengan rumus sebagai berikut:

$$
\text { Asset Turnover Ratio }=\frac{\text { Penjualan Bersih }}{\text { Total Aktiva }}
$$

Sumber: Harahap (2015)

\section{d. Likuiditas Perusahaan}

Likuiditas perusahaan berfungsi untuk menunjukkan kemampuan perusahaan dalam memenuhi kewajiban nya yang jatuh tempo, baik kewajiban terhadap pihak eksternal maupun internal perusahaan. Likuiditas pada penelitian ini diproksikan menggunakan current ratio. Dihitung dengan rumus sebagai berikut:

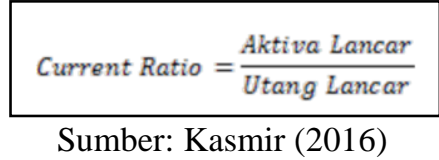

\section{e. Leverage Perusahaan}

Leverage perusahaan digunakan untuk mengukur sejauh mana perusahaan mampu memenuhi seluruh kewajibannya baik jangka pendek maupun jangka panjang. Leverage perusahaan dalam penelitian ini diproksikan menggunakan debt equity ratio. Dihitung dengan rumus sebagai berikut:

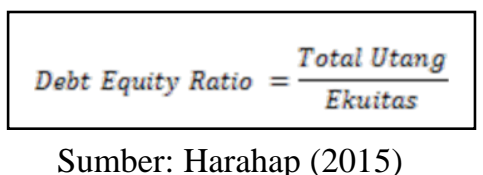

\section{HASIL DAN PEMBAHASAN}

\subsection{Karakteristik Sampel}

Penelitian ini menggunakan perusahaan manufaktur yang terdaftar di Bursa Efek Indonesia dengan tahun pengamatan 2014-2018 sebagai populasi. Adapun proses penyeleksian sampel penelitian menggunakan teknik purposive sampling. Setelah dilakukan seleksi atas populasi untuk menentukan sampel akhir berdasarkan kriteria yang telah ditentukan, maka diperoleh sampel sebanyak 104 perusahaan. 


\subsection{Hasil Analisis Deskriptif}

Analisis statistik deskriptif digunakan untuk mengetahui nilai minimum, maksimum, mean dan standar deviasi dari masing variabel berdasarkan data laporan keuangan yang telah ditentukan oleh penulis. Hasil pengujian statistik deskriptif setiap variabel dapat dilihat pada tabel 1 . berikut:

Tabel 1. Statistik Deskriptif

\begin{tabular}{|c|c|c|c|c|}
\hline Variabel & Mean & Minimum & Maksimum & Std.Deviasi \\
\hline EPS & 2.6368 & -8.0109 & 13.5219 & 3.7402 \\
\hline FS & 2.5085 & 2.3934 & 2.6767 & 0.0543 \\
\hline WC & 17.9619 & -29.597 & 30.9996 & 19.5151 \\
\hline ATR & -0.1623 & -7.105 & 2.1317 & 0.7883 \\
\hline $\mathrm{CR}$ & 0.5549 & -3.8463 & 2.7189 & 0.7648 \\
\hline LEV & -0.8535 & -3.2511 & 1.2790 & 0.6468 \\
\hline DER & -0.2118 & -3.4396 & 3.7188 & 1.0583 \\
\hline $\begin{array}{l}\text { Sampel } \\
(\mathrm{N})\end{array}$ & 520 & & & \\
\hline \multicolumn{5}{|c|}{$\begin{array}{l}\text { Keterangan: Tabel ini menampilkan hasil uji statisitik. } \\
\text { Variabel Dependen: Profitabilitas (EPS). Variabel Independen: } \\
\text { Ukuran Perusahaan (FS), Modal Kerja (WC), Efisiensi } \\
\text { Perusahaan (ATR) Likuiditas Perusahaan (CR) dan Leverage } \\
\text { Perusahaan (DER) }\end{array}$} \\
\hline
\end{tabular}

Sumber : Data diolah dengan Eviews 9, 2020

\subsection{Hasil Pengujian Asumsi Klasik}

Berdasarkan uji multikolinearitas dan uji heterokedastisitas yang mengacu pada Ghozali (2016) dapat disimpulkan data pada penelitian ini tidak mengalami permasalahan uji asumsi klasik.

\subsubsection{Uji Chow}

Uji chow digunakan untuk memilih atau membandingkan model regresi yang paling baik antara common effect dan fixed effect. Tingkat signifikan pengujian model sebesar 0,05. Berikut adalah hasil pengujian chow test pada tabel 2 dibawah ini:

Tabel 2. Hasil Uji Chow

\begin{tabular}{llllll}
\hline Variabel & Effect Test & Statistic & d.f & Prob. \\
\hline EPS & $\begin{array}{l}\text { Cros-section } \\
\text { Square }\end{array}$ & Chi- & 117.139101 & 103 & 0.161 \\
\hline
\end{tabular}

Sumber : Data diolah dengan Eviews 9, 2020

Berdasarkan tabel di atas, diperoleh nilai profitabilitas cross-section chi-square adalah 0,1613 . Nilai tersebut $>0,05$ yang menunjukkan bahwa penggunaan model common effect lebih tepat dibandingkan dengan model fixed effect, maka selanjutnya perlu dilakukan uji hausman .

\subsubsection{Uji Hausman}

Uji hausman digunakan untuk memilih atau membandingkan model regresi yang paling baik antara fixed effect dan random effect. Tingkat signifikan pengujian model sebesar 0,05. Berikut adalah hasil pengujian hausman test pada tabel 3 dibawah ini:

Tabel 3. Hasil Uji Hausman

\begin{tabular}{lllll}
\hline Variabel & $\begin{array}{l}\text { Test } \\
\text { Summary }\end{array}$ & $\begin{array}{l}\text { Chi-Sq } \\
\text { Statistic }\end{array}$ & $\begin{array}{l}\text { Chi- } \\
\text { Sq.d.f }\end{array}$ & Prob. \\
\hline EPS & $\begin{array}{l}\text { Cross-section } \\
\text { Random }\end{array}$ & 0.0000 & 103 & 1.0000 \\
\hline
\end{tabular}

Sumber : Data diolah dengan Eviews 9, 2020

Berdasarkan tabel di atas, diperoleh nilai profitabilitas cross-section random adalah 1,0000. Nilai tersebut $>0,05$ menunjukkan bahwa penggunaan model random effect lebih tepat dibandingkan dengan model fixed effect, maka selanjutnya perlu dilakukan uji lagrange multiplier.

\subsubsection{Uji Lagrange Multiplier}

Uji Lagrange Multiplier digunakan untuk memilih atau membandingkan model regresi yang paling baik antara common effect dan random effect. Tingkat signifikan pengujian model sebesar 0,05. Berikut adalah hasil pengujian lagrange multiplier pada tabel 4 dibawah ini:

\begin{tabular}{lcc}
\multicolumn{3}{l}{ Tabel 4. Hasil Uji Lagrange Multiplier } \\
\hline Variabel & Test Summary & Prob. \\
\hline EPS & Breusch-Pagan & -0.7604 \\
\hline
\end{tabular}

Sumber : Data diolah dengan Eviews 9, 2020

Berdasarkan tabel di atas, diperoleh probabilitas breusch-pagan sebesar 0,7604 . Nilai tersebut $>0,05$, maka hasil lagrange multiplier menunjukkan bahwa model common effect lebih tepat digunakan untuk model persamaan regeresi data panel. 


\subsection{Hasil Pengujian Hipotesis 4.4.1 Hasil Regresi Data Panel}

Tabel 5. Hasil Regresi Data Panel Common Effect

\begin{tabular}{llll}
\hline Variabel & Coefficient & t-Statistic & Prob. \\
\hline C & -4.613548 & -18.2277 & 0.0000 \\
FS & 11.95936 & 18.15931 & 0.0000 \\
WC & -0.521701 & -0.796536 & 0.4261 \\
ATR & 0.000962 & 4.571179 & 0.0000 \\
CR & 6.1583 & 5.810727 & 0.0000 \\
LEV & 0.000775 & 10.67789 & 0.0000 \\
DER & 1.2789 & 11.42405 & 0.0000 \\
R-squared Adjusted & 0.24066 & & \\
R-squared & 0.231779 & & \\
F-statistic & 27.09783 & & \\
Prob(F-statistic) & 0.0000 & & \\
N & 520 & & \\
Hasil Uji & Common & & \\
\hline Tingkat Signifikansi alpha 5\% & & \\
\hline
\end{tabular}

Sumber : Data diolah dengan Eviews 9, 2020

Berdasarkan hasil regresi pada tabel 5, maka model persamaan regresi data panel adalah:

$\mathrm{EPS}=4,6135+11,9593 \mathrm{FS}-0,5217 \mathrm{WC}+$ 0,0009ATR + 0,0009ATR + $6,1583 \mathrm{CR}+0,0007 \mathrm{LEV}+$ 1,2789DER

\subsubsection{Hasil Koefisien Determinasi}

Berdasarkan Tabel 5 diperoleh nilai $R$-squared untuk variabel dependen EPS sebesar 0,2407 lebih besar dari 0,05 maka menunjukkan bahwa korelasi atau hubungan antara variabel dependen EPS dan independen (FS, WC, ATR, CR, LEV, DER) sebesar $24 \%$ dan sisanya $76 \%$ dijelaskan oleh faktor-faktor lain diluar model penelitian.

\subsection{Analisis Data}

\begin{tabular}{llll}
\multicolumn{5}{c}{ Tabel 6 Ringkasan Hasil Uji Hipotesis } \\
\hline Hipotesis & Sig. & Koef. & Hasil \\
\hline \hline H1: Ukuran Perusahaan & & & \\
berpengaruh positif terhadap & 0.0000 & 11.9594 & Terdukung \\
$\begin{array}{l}\text { Profitabilitas } \\
\text { H2: Modal Kerja } \\
\text { berpengaruh positif terhadap }\end{array}$ & 0.4261 & -0.5217 & $\begin{array}{l}\text { Tidak } \\
\text { Terdukung }\end{array}$ \\
$\begin{array}{l}\text { Profitabilitas } \\
\text { H3: Efisiensi Perusahaan } \\
\text { berpengaruh positif } \\
\text { terhadap Profitabilitas }\end{array}$ & & & \\
$\begin{array}{l}\text { H4: Likuiditas Perusahaan } \\
\text { berpengaruh positif } \\
\text { terhadap Profitabilitas }\end{array}$ & & & \\
\end{tabular}

H5: Leverage Perusahaan

berpengaruh positif

terhadap Profitabilitas

$0.0000 \quad 1.2789 \quad$ Terdukung

Sumber : Data diolah dengan Eviews 9, 2020

\subsubsection{Pengaruh Ukuran Perusahaan terhadap Profitabilitas}

Berdasarkan hasil pengujian hipotesis 1 menunjukkan bahwa ukuran perusahaan berpengaruh positif dan signifikan terhadap profitabilitas. Semakin besar ukuran perusahaan maka profitabilitas perusahaan akan meningkat. Yazdanfar dan Ohman (2016) menyatakan bahwa perusahaan besar cenderung lebih menguntungkan jika dibandingkan dengan perusahaan kecil. Semakin banyak penjualan dan aset yang dimiliki akan menghasilkan perolehan laba yang besar sehingga ukuran perusahaan juga akan meningkat begitu juga sebaliknya (Kusumo \& Darmawan, 2018). Hal ini sejalan dengan penelitian yanggdilakukan oleh Nugroho (2011), Barus \& Leliani (2013), Santoso, Maryono, \& Bagana (2019), Alarussi \& Alhaderi (2018) dan Olang (2017) yang mengemukakan adanya pengaruh positif ukuran perusahaan terhadap profitabilitas. Berbeda dengan penelitian Putra \& Badjra (2015) dan Fachrudin (2011) yang menemukan bahwa ukuran perusahaan berpengaruh negatif terhadap profitabilitas.

\subsubsection{Pengaruh Modal Kerja terhadap Profitabilitas \\ Berdasarkan hasil pengujian} hipotesis 2 menunjukkan bahwa modal kerja tidak berpengaruh signifikan terhadap profitabilitas. Sejalan dengan penelitian yang dilakukan oleh Zeeshan Ahmed et al. (2016). Jumlah modal kerja yang berlebihan menyebabkan pengelolaan dana perusahaan tidak akan produktif sehingga dapat menimbulkan kerugian bagi perusahaan dan tingkat profitabilitas juga akan berkurang. Begitu juga sebaliknya, jumlah modal kerja yang tidak mencukupi kebutuhan operasional bisa menyebabkan kegagalan suatu 
perusahaan sehingga dapat menurunkan profitabiltas. Berbeda dengan penelitian yang dilakukan oleh Yani \& Martha (2019), Dharmendra (2015) dan Hasan (2013) yang mengungkapkan bahwa modal kerja berpengaruh positif dan signifikan terhadap profitabilitas. Semakin tinggi modal kerja yang digunakan dalam kegiatan operasional perusahaan akan menghasilkan produk yang lebih banyak sehingga jumlah penjualan akan meningkat. Dengan begitu, pendapatan yang diterima perusahaan akan semakin besar dan profitabilitas perusahaan akan bertambah.

\subsubsection{Pengaruh Efisiensi Perusahaan terhadap Profitabilitas}

Berdasarkan hasil pengujian hipotesis 3 menunjukkan bahwa bahwa efisiensi perusahaan berpengaruh positif dan signifikan terhadap profitabilitas. Penelitian ini sejalan dengan penelitian yang dilakukan oleh Alarussi \& Alhaderi (2018) dan Ruspandi \& Asma (2014). Semakin efisien suatu perusahaan dalam menggunakan asetnya untuk memperoleh revenue, maka perolehan profit yang diterima perusahaan akan semakin bertambah. Sebaliknya, ketidakefisienan dalam mengelola aset yang ada akan menambah beban berupa investasi yang tidak membawa keuntungan bagi perusahaan. Hasil penelitian ini bertentangan dengan penelitian Lestari (2017) dimana efisiensi perusahaan tidak memiliki pengaruh signifikan terhadap profitabilitas.

\subsubsection{Pengaruh Likuiditas Perusahaan terhadap Profitabilitas \\ Berdasarkan hasil pengujian} hipotesis 4 menunjukkan bahwa likuiditas perusahaan berpengaruh positif dan signifikan terhadap profitabilitas. Semakin besar likuiditas suatu perusahaan maka perolehan profitabilitas perusahaan juga akan bertambah. Hal ini tidak sejalan dengan penelitian yang dilakukan oleh Apriati, Salim, \& Priyono (2018) dan
Negasa (2016), Alarussi \& Alhaderi (2018) yang mengungkapkan bahwa likuiditas berpengaruh negatif terhadap profitabilitas. Hal ini menunjukkan bahwa perusahaan tidak mampu memenuhi kewajiban jangka pendeknya dikarenakan rasio lancar yang dimiliki perusahaan hanya sedikit, sehingga upaya dalam memenuhi kegiatan operasional perusahaan tidak berjalan sebagaimana mestinya. Dengan begitu likuiditas perusahaan tidak stabil dengan arus kas yang ada, mengakibatkan penurunan terhadap permintaan dan perolehan laba tidak maksimal. Penelitian ini sejalan dengan penelitian Ghurtskaia \& Lemonjava (2018) dan Santini \& Baskara (2018) menemukan bahawa likuiditas memiliki pengaruh positif dan signifikan terhadap profitabilitas. Tingginya likuiditas suatu perusahaan menandakan bahwa perusahaan berhasil melunasi hutang jangka pendeknya. Semakin baik likuiditas aktiva lancar yang dimiliki perusahaan membuat perolehan profitabilitas yang diterima akan semakin banyak.

\subsubsection{Pengaruh Leverage Perusahaan terhadap Profitabilitas \\ Berdasarkan hasil pengujian} hipotesis 5 menunjukkan bahwa leverage perusahaan berpengaruh positif dan signifikan terhadap profitabilitas. Leverage digunakan untuk meningkatkan jumlah modal perusahaan dengan tujuan agar memperoleh keuntungan, jika perolehan laba lebih besar dari beban yang timbul karena penggunaan hutang tersebut (Singapurwoko, 2011), sehingga semakin besar jumlah leverage perusahaan maka profitabilitas yang diperoleh perusahaan akan meningkat. Hal ini sejalan dengan penelitian yang dilakukan oleh Olang (2017) dan Kartikasari \& Merianti (2016). Bertentangan dengan penelitian oleh Arifin, Sarita, \& Madi (2019) yang menyatakan bahwa leverage tidak 
berpengaruh terhadap profitabilitas. Perusahaan dengan jumlah pembiayaan hutang yang besar menandakan bahwa perusahaan tidak berada pada kondisi yang baik. Selain itu, penggunaan hutang secara berlebihan dapat menyebabkan financial distress perusahaan meningkat sehingga dapat menurunkan profitabilias perusahaan. Besarnya leverage perusahaan mengakibatkan jumlah hutang yang harus ditanggung perusahaan meningkat. Jika perusahaan tidak mampu melunasi hutang tersebut, maka kegiatan operasional perusahaan tidak akan berjalan dengan lancar sehingga dapat meningkatkan risiko kebangkrutan.

\section{KESIMPULAN, KETERBATASAN DAN SARAN}

\subsection{Kesimpulan}

Penelitian ini bertujuan untuk mengetahui pengaruh ukuran perusahaan, modal kerja, efisiensi, likuiditas dan leverage terhadap profitabilitas perusahaan. Periode pengamatan dalam penelitian ini adalah tahun 2014-2018 dengan sampel sebanyak 104 perusahaan manufaktur yang terdaftar di Bursa Efek Indonesia. Berdasarkan analisis data, hasil penelitian menunjukkan bahwa ukuran perusahaan, efisiensi, likuiditas dan leverage memiliki pengaruh positif dan signifikan terhadap profitabilitas sedangkan modal kerja tidak berpengaruh signifikan terhadap profitabilitas perusahaan.

\subsection{Keterbatasan}

Keterbatasan pada penelitian ini terdiri dari: pertama, data dalam penelitian hanya menggunakan jangka waktu pengamatan selama 5 tahun, yaitu 20142018. Kedua, penelitian ini hanya menggunakan sampel perusahaan pada sektor manufaktur, sehingga ada kemungkinan munculnya hasil yang berbeda apabila menggunakan sampel di seluruh sektor perusahaan. Ketiga, terdapat cukup banyak perusahaan yang tidak memiliki laporan keuangan lengkap dan tidak menggunakan mata uang rupiah sehingga hal tersebut membatasi jumlah perusahaan yang akan dijadikan sampel dalam penelitian.

\subsection{Saran}

Berdasarkan pada keterbatasan yang telah diuraikan sebelumnya, maka saran untuk penelitian selanjutnya diharapkan dapat menggunakan sampel perusahaan selain sektor manufaktur dan pengukuran yang berbeda untuk variabel profitabilitas agar dapat melihat perbandingan hasil penelitian. Penelitian selanjutnya juga disarankan agar dapat menambah rentang waktu yang lebih lama dikarenakan perusahaan akan semakin banyak yang melakukan upaya dalam peningkatan profitabilitas dan akan menambah jumlah posisi sasaran.

\section{DAFTAR PUSTAKA}

Alarussi, A. S., \& Alhaderi, S. M. (2018). Factors affecting profitability in Malaysia. Journal of Economic Studies.

Barney, J. (1991). Firm Resources and Sustained Competitive Adventage. Journal of Management, 17(1), 99120.

Barus, A. C., \& Leliani. (2013). Analisis Faktor-Faktor yang Mempengaruhi Profitabilitas pada Perusahaan Manufaktur yang terdaftar di Bursa Efek Indonesia. Jurnal Wira Ekonomi Mikroskil, 3(2), 111-121.

Febria, R. L., \& Halmawati. (2014). Pengaruh Leverage dan Ukuran Perusahaan Terhadap Profitabilitas. 2(1).

Ghozali, I. (2016). Aplikasi Analisis Multivariate dengan Program IBM SPSS 23. Semarang: Badan Penerbit Universitas Diponegoro.

Ghurtskaia, K., \& Lemonjava, G. (2018). A Study of Relationship between Liquidity and. International 
Journal of Science and Research (IJSR), 7(4), 1609-1613.

Gitman, L. J., \& Zutter, C. J. (2012). Principles of Managerial Finance 13th Edition. Pearson Prentice Hall.

Harahap, S. S. (2015). Analisis kritis Atas Laporan Keuangan. Jakarta: Rajagrafindo Persada.

Kartikasari, D., \& Merianti, M. (2016). The Effect of Leverage and Firm Size to Profitability of Public Manufacturing Companies in Indonesia. International Journal of Economics and Financial, 6(2), 409-413.

Kasmir. (2016). Analisis Laporan Keuangan. Jakarta: Rajagrafindo Persada.

Kusumo, C. Y., \& Darmawan, A. (2018). Pengaruh Perputaran Modal Kerja, Ukuran Perusahaan, dan Disversifikasi terhadap Profitabilitas. Jurnal Administrasi Bisnis, 57(1), 83-89.

Niresh, J. A., \& Velnampy, T. (2014). Firm Size and Profitability: A Study of Listed Manufacturing Firms. International Journal of Business and Management, 9, 5764.

Nugroho, E. (2011). Pengaruh Likuiditas, Pertumbuhan Penjualan, Perputaran Modal Kerja, Ukuran Perusahaan dan Leverage terhadap Profitabilitas Perusahaan.

Olang, M. (2017). Effect of Financial Leverage on Profitability of. International Journal of Science and Research (IJSR), 6(7), 290295.

Paliwal, D. R., \& Chouhan, D. V. (2017). Relationship between Liquidity and Profitability in. International Journal of Science and Research (IJSR), 6(5), 2259-2263.

Ruspandi, H., \& Asma, R. (2014). FaktorFaktor Yang Mempengaruhi Profitabilitas Perusahaan Pembiayaan Di Indonesia. Jurnal
Wawasan Manajemen, 2(1), 97118.

Santini, N. L., \& Baskara, I. K. (2018). Pengaruh Perputaran Modal Kerja, Ukuran Perusahaan dan Likuiditas terhadap Profitabilitas Perusahaan Tekstil dan Garmen. E-Jurnal Manajemen Universitas Udayana, 6502-6531.

Santoso, S. W., Maryono, \& Bagana, B. D. (2019). Analisis Faktor-Faktor yang Mempengaruhi Profitabilitas pada Perusahaan Manufaktur yang terdaftar di Bursa Efek indonesia Periode 2015-2017. Management Dynamic Conference 5, (hal. 139145). Semarang.

Sheikh, N. A., \& Wang, Z. (2011). Determinants of capital structure: An empirical study of firms in manufacturing industry of Pakistan. Managerial Finance, 37(2), 117-133.

Singapurwoko, A. (2011). The Impact of Financial Leverage to Profitability Study of Non-Financial Companies Listed in Indonesia Stock Exchange. European Journal of Economics, Finance and Administrative Sciences, 136-148.

Tnius, N. (2018). pengaruh Modal Kerja Terhadap Profitabilitas Pada PT. Hanjaya Mandala Sampoerna TBK. Jurnal Sekuritas, 1(4), 6679.

Wicaksono, K. A. (2016). Pengaruh Leverage terhadap Profitabilitas pada Industri Makanan dan Minuman yang terdaftar di Bursa Efek Indonesia (BEI).

Yani, Y. A., \& Martha, L. (2019). Pengaruh Modal Kerja terhadap Profitabilitas pada Perusahaan Kosmetik yang terdaftar di Bursa Efek Indonesia.

Yusuf, A. (2017). Metode Penelitian Kuantitatif, Kualitatif \& Penelitian Gabungan. Jakarta: Kencana. 